Uroš D. Ćemalović ${ }^{*}$

\title{
MEMBERSHIP IN THE EU AND NATIONALISTIC DISCOURSE IN THE WESTERN BALKANS - LEGAL ASPECTS
}

\begin{abstract}
The phenomenon of refurbished ethnic nationalism, which, in the republics of former Yugoslavia, had started already in the late eighties and early nineties, have undoubtedly had devastating consequences for numerous citizens of all successor states. The armed conflicts in the 90-ies have been fuelled by the discourse based on excessive self-victimisation, highly mediatised revival of frustrations originating from the First and the Second World and nationalistic myths. In spite of the fact that the last two decades have brought relatively peaceful coexistence, the global economic crisis and new vague of migrations from Middle East and Africa have caused the revival of the nationalistic discourse all over Europe, including the countries of former Yugoslavia. However, all ex-Yugoslav countries share an important legal, political and cultural heritage, while, during at least last twenty years, the perspective (or realization) of the membership in the EU have certainly had certain calming effects on inter-ethnic relations in the entire region now often referred to as the Western Balkans. One of the important vectors of influence that the EU has - both on its member states and on candidates for membership - is the process of harmonisation of national legislations with the EU acquis. Notwithstanding the fact that the effect of this process on nationalistic discourse and hatred that it generates are mainly meta-legal and indirect, it is beyond any doubt that the EU's political agenda and its legal and economic system can give significant incentive to the reduction of interethnic tensions. The ambition of this article is to demonstrate the results in this process, the obstacles that are still on its way, as well as to propose some solutions.
\end{abstract}

Keywords: EU accession process, law harmonisation, nationalistic discourse, Western Balkans.

\section{Introduction}

Compared to numerous other ex-socialist European states, the political and legal system of the former Yugoslavia was relatively liberal, mainly in the sphere of economy - it allowed individual entrepreneurship and provided basic guarantees of private property. This was particularly the case after the break, in June 1948, with Stalin's Soviet Union, the

\footnotetext{
* Ph.D., doctor of the University of Strasbourg; Research Fellow, Institute of European Studies, Belgrade, Serbia, e-mail: contact@uroscemalovic.com.
} 
moment when - in spite of its formally neutral position in the world progressively entering in the cold war and notwithstanding the country's orientation towards the creation of the Movement of Non-Aligned Countries - the socialist Yugoslavia significantly strengthened its visible and invisible ties with the United States and numerous other Western democracies. Although the country enjoyed more than four decades of undeniable economic, societal and cultural prosperity - the situation allowing various kinds of inter-ethnic interactions and enabling the creation of strong cultural and identitary ties, which, according to some, enabled the appearance of the first generations of 'real Yugoslavs' ${ }^{1}$ - strengthening of nationalisms led to the dismantling of the federal state in the most devastating armed conflict in Europe after the $2^{\text {nd }}$ World War. The instauration of a precarious peace in 1995 did not bring a significant decrease of hate speech and nationalistic discourse in newly established post-Yugoslav states. For various political, bureaucratic and identitary reasons, it has even become inappropriate to use the term 'ex-Yugoslav' to commonly denominate the successors of the federal socialist state, while the sterile, somewhat ambivalent and politically correct term of 'Western Balkans'2 was introduced in the administrative and scientific jargon. To a certain extent, the European Union (EU) became for all SouthSlavic nations what previously was the common federal state - an entity that encourages cooperation and mutual understanding and discourages any identity-based discourse that may represent a threat for the stability and regional integration. The objective of this paper is to analyse if (through which mechanisms and with what success) the perspective of EU membership and the acceptance of its legal system could contribute in order to prevent nationalistic discourse in ex-Yugoslav countries. Consequently, the further analysis will be performed in three parts. In order to provide an appropriate historical and social perspective, in the first chapter, the focus will be on the common political, legal and cultural heritage of ex-Yugoslav countries. Subsequently, the EU-related legal and political mechanisms potentially influencing various manifestations of the nationalism will be examined in the second chapter, while the closing chapter will be dedicated to the revival of nationalism and the EU, with the focus on how to apply lessons learned from the ex-Yugoslav case. The ambition of this paper is not to analyse the causes or effects of the ethnic nationalism in the Western Balkans, but to put some more light on the possible influence that both the EU's 'soft power' and its legal or policy acts may exercise over the nationalistic discourse and practices.

\section{Common political, legal and cultural heritage of ex-Yugoslav countries}

Any endeavour aiming to analyse post-Yugoslav nationalisms and the influence the European integration may have on their practices and discourses would be incomplete

\footnotetext{
${ }^{1}$ A study from the late eighties found that over only one decade (between 1971 and 1981 censuses) 'the number of individuals who declared Yugoslav identity increased 4⿳⺈⿴囗十 fold, from 273,077 to 1,219,004' (Burg \& Berbaum, 1989, pp. 535-554).

${ }^{2}$ One may even argue that the EU gave birth to the term 'Western Balkans', given that it 'first appeared in the context of the Stabilisation and Association Process'. Branković et al. (eds), 2014, p. 66.
} 
without the reference to the several decades of common political, legal and cultural history. Moreover, the real headache for numerous researchers and social scientist ${ }^{3}$ starts when they try to explain how the years of undeniable economic prosperity in the context of a shared cultural (and linguistic) space could possibly lead to devastating hatred and militant nationalism. Therefore, in this chapter will be analysed some crucial characteristics of Yugoslav constitutional system (2.1) and common legal heritage it has produced (2.2), before turning to the reasons of the failure of common Yugoslav cultural identity against ethnic nationalisms (2.3).

\subsection{Political and economic freedoms in the context of a weakening constitutional system}

Having managed, during the turbulent three decades (1945-1975) that followed the $2^{\text {nd }}$ World War, to achieve significant advances in the fields of economy and foreign policy, the socialist Yugoslavia had developed a highly original political model. While maintaining the monopoly of the League of Communists of Yugoslavia on political and economic life of the country, the regime of President Josip Broz Tito enabled - situation impossible to imagine in any of the countries of Central and Eastern Europe belonging to the Soviet bloc - full political, diplomatic, economic and military independence of Yugoslavia. Yugoslav legal system - established by the 1953 Constitution and the two successive constitutional reforms adopted during the sixties and seventies - allowed significant political, economic and social advances and the level of liberty unfamiliar in any other state with one-party political system. Therefore, after the demise of the socialist federal government, all six Yugoslav republics continued to share a considerable legislative heritage, whose important elements, starting from their adoption, showed the intention to establish a socialist economy market ${ }^{4}$, where private property and other economic and social rights were guaranteed and protected.

The socialist Yugoslav federation has undergone two major reforms resulting from the adoption of two successive constitutions in 1963 and 1974. However, the common political and legal legacy of Yugoslav republics is the result of a weak federalism established by the second of these texts. Although it has kept the official name of the country, approved by the 1963 Constitution (Socialist Federal Republic of Yugoslavia - SFRY), the new 1974 Constitution made a profound change in country's federal model. It should first be noted that it introduced the principle according to which the decisions of federal interest, including the decision on the constitutional amendments, must meet the consensus of the delegations of six republics and two autonomous provinces within Serbia (Vojvodina

\footnotetext{
${ }^{3}$ See, for example, Cohen \& Dragović-Soso (eds), 2008; Denitch, 1997.

${ }^{4}$ Regarding the issue of somewhat controversial conception of 'socialist economy market' and the unique concept of 'socialist self-management', the doctrinal bases are presented by one of its main ideologists Edvard Kardelj in his work 'Self-management and the political system' (Socialist Thought and Practice, 1980). For a more global perspective of the issue, see Estrin, 2010.
} 
and Kosovo $)^{5}$. Moreover, this text had declared - in the context of a vague wording of its preamble - that the nations of Yugoslavia established the federal state 'based on the right of self-determination, including the right of secession, of every nation' (Constitution SFRY 1974, Preamble). Many legal and political scientists ${ }^{6}$ consider that such a conception of federalism could only strengthen the centrifugal political forces and endanger the viability of the federation. The weakness that the federal state has shown in the second half of the eighties, as well as its swift implosion after several successive declarations of independence, rapidly confirmed the validity of this standpoint. Country's weak constitutional basis and devastating effects of Serbian, Croatian and Bosnian nationalisms had put an end to the Second Yugoslavia and heavily deteriorated the relations between the newly born countries in the region of Western Balkans.

\subsection{Importance of the federal legal heritage}

Despite the week constitutional basis of the socialist Yugoslavia, numerous laws adopted between 1945 and 1990 are still in effect in all countries established after the dismantling of the federal state. Even though few legal experts would now admit it especially if they are still under the influence of the nationalistic concept of the 'greatness and uniqueness' of their newly born country - some substantially very good laws were adopted in ex-Yugoslavia. This was especially the case the Yugoslav (federal) Law on Obligations, adopted in 1978, the act that, besides its undisputed nomotechnical quality, guaranteed effective and modern contractual relations. In this and similar cases, national law-making authorities were only supposed to operate the reception of the Yugoslav legal heritage in their national legal system. The benefit for the new model of cooperation in the region is clear: the legal basis for trade and other private-law related operations is generally similar in all the countries of the region.

Politically and legally more demanding are the cases when the national legislator is facing legal tabula rasa, weather because the socialist Yugoslavia has not adopted laws in certain fields or, as it was more often the case, because the new law-making authority too rapidly and with too much arrogance abrogated federal laws. In this case, the EU model of harmonization and/or unification of laws and its amazing textual result (hundreds of pages of so-called acquis communautaire) could be the good example for ex-YU countries. However, even if it is clear that this approach could be followed in some formal aspects of normative convergence, the substance of the new legal solutions should take into account: 1) the nature and importance of each country's commercial relations and 2) its eventual ambition to join the EU.

Finally, the nature of the commercial relations of ex-Yugoslav countries mentioned in the context of the law making is, maybe, the key for understanding the substance of the

\footnotetext{
${ }^{5}$ Article 398 of the 1974 Constitution provided that 'any decision involving an amendment to the Constitution of the SFRY shall be adopted by the Federation Chamber of the SFRY Assembly, with the consent of the assemblies of all republics and autonomous provinces' (Constitution SFRY, 1974).

${ }^{6}$ See, for example, Kavalski \& Zolkos, 2008.
} 
new model of cooperation. Economic systems of all six Yugoslav federal republics were, during the last 50 years, established and developed to be fully complementary; devastating consequences of armed conflicts in Croatia (1991-1995) and Bosnia (1992-1995) could not considerably change this fact. Therefore, every significant step in economic cooperation on European or international level will certainly be the function of the ability to establish and maintain prosperous and sustainable cooperation in the region.

\subsection{Common Yugoslav cultural identity and how it failed against ethnic nationalisms}

The notion of culture and, consequently, the concept of cultural identity, are complex and multifaceted phenomena. Moreover, the cultural progress is often seen as a mere function or a direct consequence of economic growth, given that, 'as an epiphenomenon, culture represents a projection of economic development in mind [...] with definite forms of culture corresponding to each stage of economic progress' (Greenfeld, 2016, p. 85). In the same vein, 'nationalism, being essentially a matter of culture, and corresponding chronologically to the development of capitalism and industrialization, is therefore seen as either a reflection or a functional prerequisite of economic modernization' (Greenfeld, 2016, p. 85 - Ref. 8). While this reasoning may be true for $19^{\text {th }}$ century nationalism in Western Europe, it is inapplicable to ex-Yugoslav ethnic nationalisms in the late $20^{\text {th }}$ century. More precisely, several decades of shared political and economic development have created a significant common heritage, where 'political governance of Yugoslav socialist community translates itself into a project of national cultural defining and distilling Yugoslav cultural identity' (Mišina, 2013, p. 8). In other words, ethnic nationalisms slowly developing already from the early seventies within constituent nations of Yugoslavia were neither a reflection, nor - even less possible to imagine - 'functional prerequisite' of economic modernization. The picture becomes even more complex when one takes into consideration that the process of 'ethnification' of then-republics of Yugoslavia was concomitant with the process of undeniable construction of an overarching, Yugoslav political and cultural identity. What are the main reasons why identitary particularisms and centrifugal political tendencies triumphed over the unifying forces of non-negligible common social, cultural and - as it was demonstrated in previous sub-chapters - legal and political heritage?

Because of disintegrative tendencies materialised by the significant increase of competencies of federal units by 1974 Constitution, the capitals of all six republics - and, to some extent, two autonomous provinces - became the epicentre of numerous important political and social processes. While the freedom of movement of persons, goods and capital, as well as the common economic and cultural space, were strongly working in favour of inter-republic and trans-ethnic cooperation, the revamped nationalistic elites in Serbia and Croatia were progressively introducing the discourse based on nationalistic myths, using the self-victimisation and perfidiously reviving historical frustrations. Permissive, disinterested and, very often, corrupted and incompetent federal political elites were unable or unwilling to put an end to more and more direct and aggressive verbal expressions of nationalism. Moreover, from the early eighties, the religious authorities of all 
three big confessions started to participate more openly in the social and political life, most often fuelling ethnic resentments and invoking danger of proselytism whenever they felt the 'national and religious unity' was put in danger. As a sum of all mentioned phenomena combined with economic crisis of mid-eighties, the common Yugoslav cultural identity and resulting values were in retreat, so much so that the refurbished nationalisms could happily contemplate the multi-ethnic country disappearing in the flame of armed conflict.

\section{The indirect influence of the $\mathrm{EU}$ in the prevention of nationalistic discourse}

The direct interference of the EU in the interior political affairs of its member states and candidates for membership is not in accordance with the primary law and basic principles on which the Union is founded. This is a consequence of the fact that, on the one hand, the Member States confer competences on the EU 'to attain objectives they have in common', while, on the other 'competences not conferred upon the Union in the Treaties remain with the Member States' (Article 4 of the TEU). However, throughout the membership negotiation process with a candidate country, various EU institutions and instances have numerous opportunities - via, among others, the opening and closing benchmarks for some of negotiation chapters, and especially those related to judiciary and fundamental rights (Chapter 23), justice, freedom and security (Chapter 24) and foreign, security and defence policy (Chapter 31) - to influence - and, to some extent, even forge - the interior political developments within the candidate country negotiating its future membership. A relatively direct political influence can also be carried out through the mechanisms of Union's external action and its common foreign and security policy, which is clearly demonstrated by the substantive involvement of the European External Action Service (EEAS) and the High Representative of the Union for Foreign Affairs and Security Policy in the process of negotiation between Belgrade and Pristina authorities. However, all these 'heavy weight' mechanisms will not be analysed in this chapter, given that they do not represent the long-standing processes which can seriously and more permanently influence the nationalistic political discourse in a candidate country or, to some extent, member state. On the other hand, what will be examined here is the role of a grand political orientation - such as the decision to join the EU - and its consequences - such as the harmonisation of national legal systems with the EU acquis - in the weakening or strengthening of social and political factors influencing the nationalism and its presence in public discourse.

\subsection{Potential membership in the EU - from a calming effect to an irritating disappointment}

In all states established after the disintegration of socialist Yugoslavia, the clear political orientation towards the membership in the EU was set already in the nineties (for Serbia in 2000), but (for all except Slovenia) it became fully politically operational

\footnotetext{
${ }^{7}$ Article 1 of the Treaty on European Union (TEU), 2010 OJ C 83, 13.
} 
after the European Council and the EU-Western Balkans Summit of Thessaloniki, held in June 2003 and often treated as 'a milestone's in the EU's relations with this geographical zone of potential enlargement. Very soon, it became clear that the good relations between all the states that share the EU membership aspirations is vital for their future accession, given that fragmentation and divisions along ethnic lines are incompatible with the European perspective, which should act as a catalyst for addressing problems in the region' (Paragraph 5-3 of the Declaration issued after the EU-Western Balkans Summit, 2018). The political discourse is programmatic and highly proclamatory, while the word 'ethnic(ally)' appears four times in the Thessaloniki Declaration, out of which three times only in paragraph 5. Almost every political, diplomatic or societal challenge is seen under the auspices of ethnicity: 'sustainable return of refugees and internally displaced persons is critical for ethnic reconciliation' (Paragraph 5-2 of the Declaration issued after the EUWestern Balkans Summit, 2018), while 'the role of education, culture and youth (is) in promoting tolerance, ensuring ethnic and religious coexistence and shaping modern democratic societies' (Paragraph 5-2 of Declaration issued after the EU-Western Balkans Summit, 2018). The political spill-over effect this ethnic-based perspective have had on the internal political discourses in the Western Balkans countries is undeniable. The party leaders and opinion-makers understood that politically correct language imposes affirmative treatment of 'ethnic reconciliation' and 'ethnic coexistence'. Notwithstanding the undisputedly positive effects such orientation and practice have had on the real interethnic relations - both between diverse groups within each of the countries and between the ex-Yugoslav states previously involved in armed conflicts - it was, very often, purely proclamatory and emptied of any real political content.

The 'enlargement fatigue' is a notion present in the EU-related literature for almost a decade; it indicates the saturation of public discourse with diverse negative effects of 2004 and, especially, 2007 enlargements, but it also implies the inaptitude of various EU structures to keep up the EU's attraction in the eyes of candidate countries and their respective populations. In other words, this 'fatigue' is 'another factor that undermines the EU's ability to use accession conditionality for foreign-policy objectives' (Walace, Pollack \& Young (eds), 2015, p. 432). The counterpart of this phenomenon in candidate countries - the importance of which is considerably accentuated by global economic crisis, interior political instability and migratory crisis - is the similar saturation by the EU-related issues and even more accentuated disillusion concerning the benefits of country's European orientation and efforts invested in more and more uncertain accession. Such a constellation of irritating disappointments - with both the EU as a political project and its positive effect for citizens - is additionally emphasised by the media and, as such, represents an ideal opportunity for extreme-right and extreme-left nationalistic and/or neo-communist political agendas, out of which many use openly nationalistic discourse. Every political event, such as Brexit, that weakens the EU is seen as a blessing by such political forces, while the slowness of EU's enlargement-related bureaucratic procedures slowly but gradually contributes to the refurbishment of ethnic particularism and nationalism.

\footnotetext{
${ }^{8}$ European Commission, Press Release Ip/03/860, Brussels, 18 June 2003, 'The Thessaloniki Summit: a milestone in the European Union's relations with the Western Balkans'.
} 


\subsection{Role of the harmonisation of national legal systems with the EU acquis}

The issue of law approximation necessary for the EU accession is often seen as highly technical question and, consequently, devoid of any significant interest in public discourse and media. However, the real, substantial changes in national political and economic systems - as well as in the real, everyday life of the citizens of candidate countries - can only be made through gradual changes of the legislation, influencing social, economic and political realities. Harmonisation of various provisions of internal legal systems with the EU law, policy the objective of which is is to eliminate the inconsistent differences in national legislations'(Ćemalović, 2015, p. 258) cannot, as such, significantly influence the global presence of nationalism and identitary discourse. However, the progressive alignment of various factors influencing day-to-day functioning of industry, commerce, transport and communication - allowing faster and easier cross-border movement of persons, goods and ideas - can have quite indirect, but tremendously positive effects on the retreat of nationalistic feelings. Given that every identitary speech is based on constructs reflecting the uniqueness and endangered specificity of one group, the mere possibility for more trans-national interaction can have far-reaching positive consequences. On the EU level, the progressive implementation of the legislation reducing the costs of roaming ${ }^{9}$ provides a sound example, given that 'this approach strengthens the EU's output legitimacy, which is especially important, as citizens increasingly have the impression that the EU has lost its ability to produce concrete added value' (Kaczyński, 2009, p. 7). Applied to candidate countries of the Western Balkans, such strategies have a good potential not only to improve the Union's image, but, more importantly, to allow more substantial channels of crossborder communication and cooperation and, consequently, to contribute to the reduction of nationalistic feelings and practices.

\section{Revival of nationalism and the EU: how to apply lessons learned from the ex-Yugoslav case?}

Over the last decade, the progressive revival of nationalism was not an exclusive particularity of the countries of the Western Balkans. The global economic and, more recently, migratory crisis, have had undeniable effects and the refurbished nationalism - often referred to as 'the new nationalism' - has shown its strength in a series of parliamentary and presidential elections all over Europe. Here it would suffice to mention the two revealing examples. The percentage of votes gained by anti-European, isolationist and nationalistic UK Independence Party (UKIP) at British parliamentary elections has grown from $3.1 \%$ (2010 elections) to $12.6 \%$ (2015 elections); in spite of the fact that 'the UKIP's public support did not translate into seats' (Kubicek, 2017, p. 256) the tendency was clear. The real political earthquake of Brexit happened one year later, and it is difficult

\footnotetext{
${ }^{9}$ According to the European Commission's Strategy for Digital Single Market (COM/2015/0192 final), 'the EU has ended roaming surcharges for all people who travel periodically within the EU', given that 'roaming charges have been gradually reduced starting from 2006', while 'since 15 June 2017, people pay only domestic charges'.
} 
to claim that it was not timely and adequately announced by the rise of anti-immigrant and anti-EU political discourse. Another sound example are the last Polish presidential (May 2015) and parliamentary (October 2015) elections. Without entering into the particularities of electoral processes and their results, two important mentions should be made. The surprise that the electoral block led by Pawet Kukiz made in the first round of presidential elections has shown that the electorate was more and more open to the farright extremist ideas, even when political newcomers often openly using the hate speech present them. Subsequently, the success that 'more nationalistic (particularly vis-à-vis Germany and Russia) and critical of the EU' (Kubicek, 2017, p. 256) political discourse has made on parliamentary elections was not a surprise.

Notwithstanding some recent positive developments in Europe (good examples are the Austrian presidential and Dutch and French parliamentary elections) - and regardless certain political and historical particularities of the states of Western Balkans established after 1990 - the lessons, learned from ex-Yugoslav case, about fast-spreading and devastating features of nationalism are widely applicable to the 'new nationalisms' refurbishing all over Europe. Based on the analysis performed and conclusions made in Chapter 3, here the focus will be on the possible transformative influence of EUrelated legal and policy instruments on nationalistic discourse; most of the conclusions and recommendations are equally applicable to both member states and candidates for membership.

1. Economic development, progress in the establishment of common (interior) market and deepening of economic relations - as well as parameters such as growth of global GDP, reduction of unemployment or improvement of the quality of life - do not necessarily imply the reduction of nationalistic feelings and the readiness of various political factors and media to use/spread ethnic stereotypes, nationalistic myths and discourse based on self-victimisation. As the examples of ex-Yugoslavia in early nineties and several EU member states over last 5 years have clearly shown, relative prosperity and several decades of undoubted economic progress are not the guarantee that the attachment to common values and principles, the increasing convergence of attitudes to life, the awareness of having specific interests in common' (Paragraph 3 of the Declaration on European Identity, adopted in Copenhagen on 14 December 1973) have definitely won the battle over particularisms and destructive nationalism.

2. For the countries that are candidates for the EU membership, the perspective of joining the Union certainly has, in the short term, numerous positive repercussions related to the reduction of nationalistic discourse and determination to take part in the construction of a United Europe' (Kaczyński, 2009, p. 7). However, the slowness of EU’s enlargement-related procedures progressively darkens the perspective of integration, provoking the resentment of 'unwanted partner' and, consequently, inciting irritation and relapse of nationalism.

3. In such a context, only effective and tangible EU legislative and policy initiatives - visible and present in everyday life of citizens - have a potential to increase convergence and reduce the impact of identity-based discourses. Projects such as Erasmus and 
Erasmus $+{ }^{10}$ or legislative efforts such as those facilitating movement and communication, can significantly improve the sustainable transnational understanding and, as some authors suggested, even initiate the creation of a 'space for transcultural existence' (Tamcke, 2013). As the ex-Yugoslav example clearly shows, even (to a significant extent) shared language and important elements of common cultural identity cannot prevent the risks of nationalistic discourse paving the path to armed conflict.

\section{Conclusion}

In spite of a significant common political, legal and cultural heritage shared by the former republics of socialist Yugoslavia, important elements of partially achieved transethnic identity could not prevent the devastating consequences of identitary discourse and destructive nationalism. On the other hand, the role of a grand political orientation (decision to join the EU) and its consequences (harmonisation of national legal systems) have undeniable effects on weakening or strengthening of social and political factors influencing the nationalism and its presence in public discourse. On the basis of universally applicable conclusions that could be made through the analysis of both EU's policy and legal instruments applied to the case of Western Balkans, this paper endeavoured to formulate a number of conclusions and recommendations equally applicable to both member states and candidates for membership. It is argued that possible transformative influence of EUrelated legal and policy instruments on identity-based discourse is globally unrelated with the overall economic conjuncture, while only the initiatives with tangible transcultural effects can have a potential to increase convergence and reduce the impact of nationalistic practices and discourses.

\section{References}

Branković, J., Vukasović, M., Kovačević, P. Maasen, P. \& Stensaker B. (eds). 2014. The Re-Institutionalization of Higher Education in the Western Balkans: The Interplay between European Ideas, Domestic Policies and Institutional Practice. Frankfurt am Main: Peter Lang Edition.

Burg, S. \& Berbaum, M. 1989. Community Integration and Stability in Multinational Yugoslavia. American Political Science Review, 83(2), pp. 535-554.

Ćemalović, U. 2015. Framework for the Approximation of National Legal Systems with the European Union's Acquis: From a Vague Definition to Jurisprudential Implementation. Croatian Yearbook of European Law and Policy, 11, pp. 241-258.

Cohen, L.J. \& Dragović-Soso, J. (eds). 2008. State Collapse in South-Eastern Europe: New Perspectives on Yugoslavia's Disintegration. West Lafayette: Purdue University Press.

Denitch, B. 1997. Ethnic Nationalism: The Tragic Death of Yugoslavia. Minneapolis: University of Minnesota Press.

\footnotetext{
${ }^{10}$ See, for example, Feyen \& Krzaklewska (eds), 2012; Mutlu, 2015.
} 
Feyen, B. \& Krzaklewska, E. (eds). 2012. The ERASMUS Phenomenon - Symbol of a New European Generation?. Frankfurt am Main: Peter Lang Edition.

Greenfeld, L. 2016. Advanced Introduction to Nationalism. Cheltenham: Edward Elgar.

Estrin, S. 2010. Self-Management: Economic Theory and Yugoslav Practice. Cambridge: Cambridge University Press.

Kaczyński, P.M. 2009. The European Commission 2004-09: A politically weakened institution? Views form the National Capitals. Working Paper 23, European Policy Institutes Network.

Kavalski, E. \& Zolkos, M. 2008. Defunct Federalisms: Critical Perspectives on Federal Failure. London: Routledge.

Kubicek, P. 2017. European Politics. London: Routledge.

Mišina, D. 2013. Shake, Rattle and Roll: Yugoslav Rock Music and the Poetics of Social Critique. London: Routledge.

Mutlu, S. 2015. The Development of European Identity in Erasmus Students: Content Analysis of Experience Stories of Erasmus Students. Saarbrücken: Omniscriptum.

Tamcke, M., de Jong, J., Klein L. \& Van der Waal, M. 2013. Europe - Space for Transcultural Existence?. Göttingen: Universitätsverlag.

Walace, H., Pollack, M.A. \& Young, A.R. (eds). 2015. Policy-making in the European Union. Oxford: Oxford University Press.

\section{Legal sources and policy documents}

Declaration issued after the EU-Western Balkans Summit, 2018. Available at: $h t t p: / / e u r o p a$. eu/rapid/press-release_PRES-03-163_en.htm, (12.6.2019).

Declaration on European Identity, 1973. Bulletin of the European Communities, December 1973, No 12, pp. 118-122. Luxembourg: Office for official publications of the European Communities. Available at: https://www.cvce.eu/content/publication/1999/1/1/02798dc99c69-4b7d-b2c9-f03a8db7da32/publishable_en.pdf(12.6.2019).

European Commission's Strategy for Digital Single Market, 2015. Communication from the Commission to the European Parliament, the Council, the European Economic and Social Committee and the Committee of the Regions A Digital Single Market Strategy for Europe, COM/2015/0192 final. Available at: $h t t p s: / / e u r-l e x . e u r o p a . e u /$ legal-content/EN/TXT/?uri=celex\%3A52015DC0192 (12.7.2019).

Treaty on European Union (TEU), [2010] OJ C 83, 13.

Constitution SFRY, 1974. Constitution of the Socialist Federal Republic of Yugoslavia. Available at: https://www.worldstatesmen.org/Yugoslavia-Constitution1974.pdf, (11.6.2019).

\section{Website References}

European Commission, Press Release Ip/03/860, Brussels, 18 June 2003, 'The Thessaloniki Summit: a milestone in the European Union's relations with the Western Balkans'. Available at: https://europa.eu/rapid/press-release_IP-03-860_en.pdf, (12.6.2019). 


\section{Dr Uroš D. Ćemalović}

Naučni saradnik, Institut za evropske studije, Beograd, Srbija

e-mail:contact@uroscemalovic.com

\section{ČLANSTVO U EU I NACIONALISTIČKI DISKURS NA ZAPADNOM BALKANU - PRAVNI ASPEKTI}

\section{Sažetak}

Potpirivanje međunacionalne netrpeljivosti, koji se rasplamsalo krajem osamdesetih i početkom devedesetih godina prošlog veka, imalo je tragične posledice za sve novonastale države u regionu Zapadnog Balkana. To je posebno bio slučaj kada su u pitanju odnosi između republika bivše Jugoslavije, čija se koegzistencija u okvirima federalne države završila nizom pogubnih oružanih sukoba, koji su podsticani oslanjanjem na nacionalističke mitove, auto-viktimizaciju i oživljavanje istorijskih trauma koje su imale svoje poreklo u prethodnim ratovima. Svi ovi fenomeni, kao i tenzije koje su izazvali, u širem evropskom kontekstu su doživeli delimično oživljavanje zbog globalne ekonomske i migracione krize, čineći pojavu koja se često označava terminom „novi nacionalizam“. Sa druge strane, sve države bivše Jugoslavije dele značajno i opsežno pravno, političko i kulturno nasleđe, dok, tokom već najmanje prethodne dve decenije, perspektiva (ili realizacija) članstva u Evropskoj uniji (EU) nesumnjivo ima izvesne smirujuće efekte na međunacionalne odnose u regionu Zapadnog Balkana. Jedan od značajnih vektora uticaja koje EU ostvaruje kako na svoje članice, tako i na države kandidate za članstvo, tiče se i procesa usklađivanja nacionalnih zakonodavstava sa pravnim tekovinama Unije. Iako su efekti ovog procesa na nacionalistički diskurs i netrpeljivost koju izaziva uglavnom meta-pravni i posredni, nesumnjivo je da politička agenda EU i njeno pravno-ekonomsko uređenje mogu značajno da utiču na smanjivanje međunacionalne netrpeljivosti. Ambicija ovog članka je da ukaže na ostvarene rezultate u ovom procesu, prepreke koje mu stoje na putu i neka od mogućih rešenja.

Ključne reči: proces pristupanja EU, usklađivanje zakonodavstva, nacionalistički diskurs, Zapadni Balkan.

Article history:

Received: 3 September 2019

Accepted: 27 January 2020 